\title{
DYNAMICS OF THE MONORAIL TRAIN SUBJECTED TO THE BRAKING ON A STRAIGHT GUIDEWAY BRIDGE
}

\begin{abstract}
A finite element (FE) model of the straight guideway bridge under monorail train has been built in this research in order to investigate dynamic interactions of the coupled system in the vertical and longitudinal direction. A limited length of the straddle monorail bridge including five continuous spans is modeled in three dimensions by using FE method. A 3D model of the monorail train system, built in the multibody analyzer MSC ADAMS, is assembled over the bridge. The entire model, consisting of the vehicle and bridge subsystems, is numerically analyzed by performing dynamic simulation in time domain. The braking forces between the train tires and guideway beams are activated in the analysis, in addition to the dead weights of the components and the train live loads. Dynamic forces in the tires are obtained for the case of the emergency braking in the system. The reaction forces, appeared in the bridge piers, are reported as the input forces for the purpose of the bridge design.
\end{abstract}

\section{Introduction}

A train running at a monorail bridge is a type of dynamical systems which interacts with the bridge structure. Such a coupled system is a source of high noise and vibration levels. Many bodies comprise the train system and so it has many degrees of freedom. The bodies that make up the vehicle can be connected in various ways and a moving interface links the vehicle to the monorail bridge.

Until now, there have been various techniques available in order to perform dynamic analysis of the monorail bridge-train system. These techniques can be sorted in two general categories i.e. analytical (computational) methods and computer-based models. In the former category, the monorail vehicle and

* Iran University of Science and Technology, School of Railway Engineering, Tehran, Iran; E-mail:meysam_naeimi@yahoo.com

** Tarbiat Modares University, Department of Mechanical Engineering, Tehran, Iran.

*** Ferdowsi Mashhad University, Department of Mechanical Engineering, Mashhad, Iran. 
the bridge were modeled by the set of beams, viscoelastic spring/dampers and masses, representing the dynamics of the vehicle-bridge system; see e.g. [1-6]. These works investigated the vibration of the monorail bridges under moving trains or external loads by extracting the equations of motion for the elements and by fulfilling the dynamic interaction of the components. As for Hittachi monorail system in Japan, Lee, et al. [2, 3] investigated the dynamic response of a monorail bridge under the train movement. They considered each monorail car as a system of 15-degrees-of-freedom (DOF), by which the governing equations of motion for a three-dimensional (3D) monorail bridge-train system were derived using the Lagrange's formulation. To assess the level of the vibration generated by the monorail system, Rybak, et al. [7] performed a combination of the theoretical and experimental studies, where a physical model of the wagon-viaduct-soil system was proposed and numerically analyzed. $[8,9]$ are other examples that performed experimental observations on dynamic behavior of the monorail systems. The study on the influence of the high-speed monorail system on bridges has been reported by Ivanchenko [4], where the substructure method was developed for the system.

In contrast to the theoretical methods, fewer investigations addressed the dynamics of the monorail train-bridge system by using computer programs for the finite element modeling and mutibody simulation. As an example of this, Wang, et al. [10] used FEM to model the monorail structure using a FE tool and to obtain the stress, strain, natural frequencies and resonance responses of the system. Based on this analysis, they optimized the design of the monorail system with ensuring security and stability in mountain areas. In another work, Wen, et al, [11] considered the straddle-type monorail under the vehicle by finite element modelling and analyzed the possible crash between monorail vehicle and the surrounding walls.

In a recent study, Naeimi, et al. [12] investigated the dynamic interaction of the monorail-bridge system by combining the finite element method and multibody analysis. This work presented an innovative numerical model for the train-guideway interaction problem, considering a typical monorail train and a limited length of the monorail bridge. The entire dynamic model of the vehicle-bridge system, consisting of all flexible and rigid body elements, was numerically analyzed in the multibody dynamics environment. Such a dynamic model was developed for a curved track structure without considering the traction or braking efforts between the train and the guideway system. In the present research, however, the longitudinal forces between the train tires and guideway beams are introduced in the dynamic analysis. The present study utilizes the same numerical procedure of [12] for dynamic simulation of the monorail train-bridge system, while the guideway structure is considered to be straight and the braking forces are taken into account. 


\section{Dynamic modeling technique}

The general specifications of the train and monorail bridge system are considered according to the Qom monorail project in Iran; see Fig. 1. The first phase of this project consists of around six kilometers of straddle monorail track with seven stations, linking the north-eastern part of the city with the grand mosque in the center of the city.

(a)

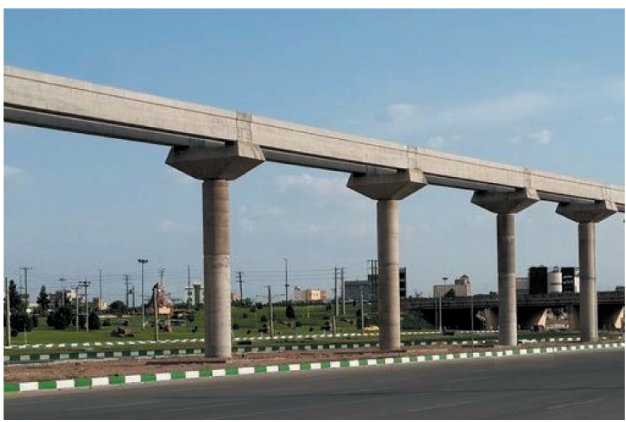

(b)

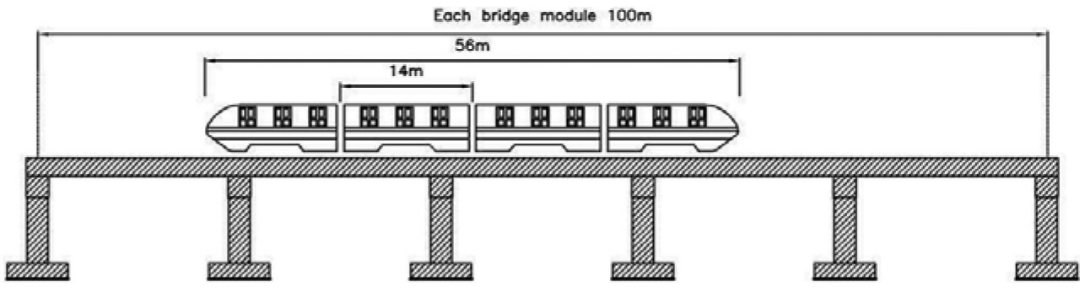

Fig. 1. (a). The view of the final monorail bridge structure in Qom, (b) schematic view of the train system on the typical bridge spans

The multibody dynamics (MBD) simulation program MSC ADAMS and the FE tool ANSYS-APDL are used to model the train-bridge system. According to the general specifications of the train system and the bridge structure in Qom monorail project, the coupled model is fabricated in the MBD environment. The detailed procedure can be found in [12].

The vehicle consists of four monorail cars (Fig. 1b), each of them running on two single axle rubber tire bogies. The load bearing tires act as the bogie primary suspension. The secondary suspension of the bogie is provided by the pneumatic air springs and shock absorbers fitted between the bogie frame and the bogie bolster. The air spring is equipped with a leveling mechanism to compensate for the deflection of the secondary suspension under different loading conditions. Fig. 2 shows the bogie subsystem modeled in this research. General specifications of the elements, connectors, springs and dampers are given in Table 1 according to [13]. 


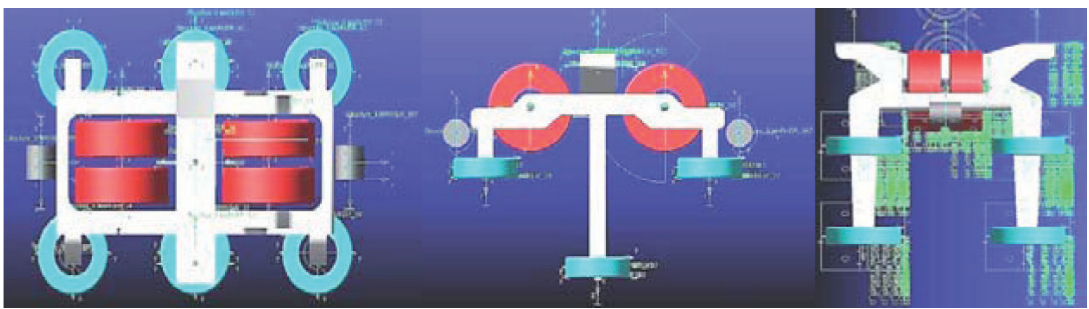

Fig. 2. The bogie subsystem modeled in the MBD tool, different $2 \mathrm{D}$ views of the $3 \mathrm{D}$ model

There are two bogies carrying the loads of in each monorail car. The train composition (Fig. 3) consists of two end cars and two middle-cars. This is the most popular principle used in the existing monorail systems.

Table 1.

Detailed parameters and specifications of the monorail vehicle

\begin{tabular}{|l|c|}
\hline \multicolumn{1}{|c|}{ Parameters } & values \\
\hline Length for end cars & $13500 \mathrm{~mm}$ \\
\hline Length for end car over coupler & $14000 \mathrm{~mm}$ \\
\hline Length for middle cars & $12500 \mathrm{~mm}$ \\
\hline Length for middle car over coupler & $13000 \mathrm{~mm}$ \\
\hline Overall width & $3100 \mathrm{~mm}$ \\
\hline Height (rooftop to top of running surface) & $3020 \mathrm{~mm}$ \\
\hline Overall height (rooftop to the tire bottom) & $4050 \mathrm{~mm}$ \\
\hline Bogie system per car & two axle dual tires \\
\hline Suspension system & pneumatic spring \\
\hline Tire diameter (load bearing tires) & $800 \mathrm{~mm}$ \\
\hline Tire diameter (guiding tires) & $600 \mathrm{~mm}$ \\
\hline Total mass of each wagon (full passenger load) & $35.6 \mathrm{ton}$ \\
\hline Maximum design speed & $80 \mathrm{~km} / \mathrm{h}$ \\
\hline Mass of car body (passenger loaded) & $15 \mathrm{ton}$ \\
\hline Mass of each bogie & $10.3 \mathrm{ton}$ \\
\hline Spring constant of vertical air suspension & $900 \mathrm{kN} / \mathrm{m}$ \\
\hline Damping coefficient of vertical air suspension & $23 \mathrm{kNs} / \mathrm{m}$ \\
\hline Normal contact stiffness of driving wheels & $6000 \mathrm{kN} / \mathrm{m}$ \\
\hline Damping coefficient of driving wheel contacts & $330 \mathrm{kNs} / \mathrm{m}$ \\
\hline Normal contact stiffness of guiding wheels & $5000 \mathrm{kN} / \mathrm{m}$ \\
\hline Damping coefficient of guiding wheel contacts & $180 \mathrm{kNs} / \mathrm{m}$ \\
\hline Friction coefficient between tire and concrete & 0.6 \\
\hline
\end{tabular}




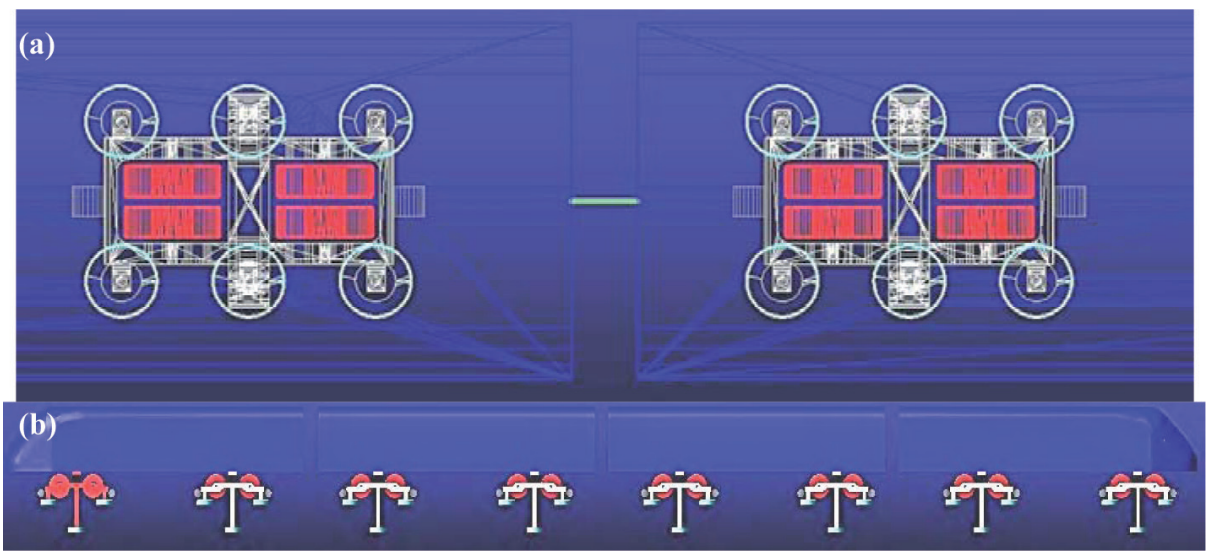

Fig. 3. Modeling of the train composition in the MBD tool, (a) top view of two bogies,

(b) side view of the entire vehicle

The guideway structure generally consists of individually precast reinforced concrete beams, which are erected and stitched together with in-situ concrete and consequently integrated with continuous reinforced bars to form a continuous frame up to five spans. The nominal span of the guideway beams ranges from $20 \mathrm{~m}$ to $30 \mathrm{~m}$, however, a typical span of $20 \mathrm{~m}$ has been considered in this study. This model includes a typical module of the bridge structure on the straight track (without horizontal/vertical curves) with the continuous spans of 100 m; see Fig. 4. As shown in Fig. 4, any of the 100m-long bridge modules has 5 spans with equal length of $20 \mathrm{~m}$. Indeed, the typical module of the bridge system includes a continuous guideway system resting on two side piers and four middle piers. Table 2 lists the specifications of concrete material and reinforcement bars (steel rebar) for structural modelling extracted from [14].

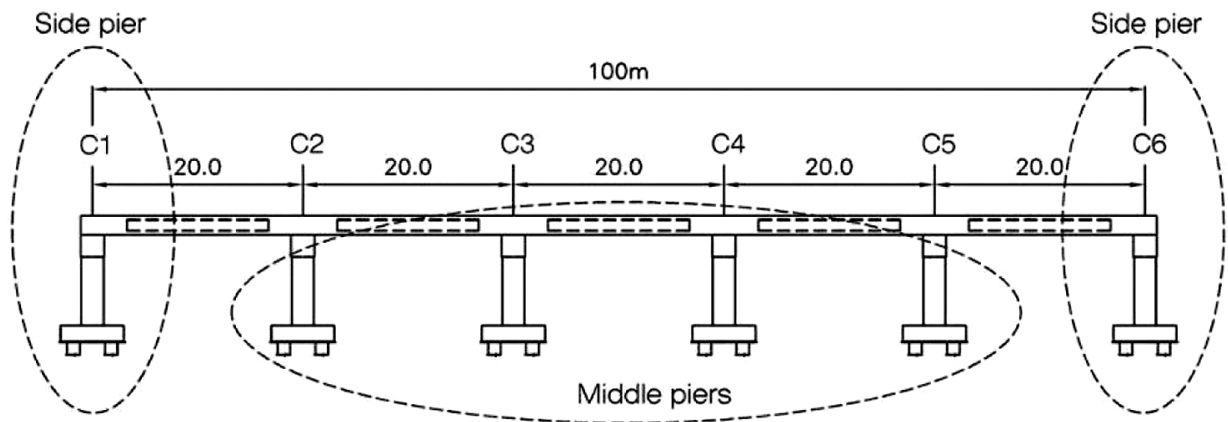

Fig. 4. Monorail bridge structure (typical modules) 
Table 2 .

Concrete/ steel material specifications for modelling

\begin{tabular}{|l|c|c|c|}
\hline \multicolumn{1}{|c|}{ Concrete parameters } & Quantity & Steel parameters & Quantity \\
\hline Elasticity module & $25743 \mathrm{MPa}$ & Type of steel bars & High strength deformed \\
\hline Compressive strength & $30 \mathrm{MPa}$ & Standard type & BS 4449 \\
\hline Tensioning strength & $3.4 \mathrm{MPa}$ & Elasticity module & $210000 \mathrm{MPa}$ \\
\hline Impact coefficient of tension /hear & 1 & Yield strength & $460 \mathrm{MPa}$ \\
\hline Impact coefficient of compression & 0 & Poison's ratio & 0.3 \\
\hline Poison's ratio & 0.2 & & \\
\hline 28-day compressive strengths & $45 \mathrm{MPa}$ & & \\
\hline
\end{tabular}

The guideway beams have the box cross section with $850 \mathrm{~mm}$ width and the depth varying from $1600 \mathrm{~mm}$ to $2200 \mathrm{~mm}$. The typical depth of $1600 \mathrm{~mm}$ is considered in this research. The main components of the bridge structure are given in Fig. 5. The structural specification of the bridge system are taken from [14]. Fig. 6 illustrates the FE model of the monorail bridge in this research. The final dynamic model of the vehicle-bridge system is built in the MBD tool using the coupling procedure presented in [12].

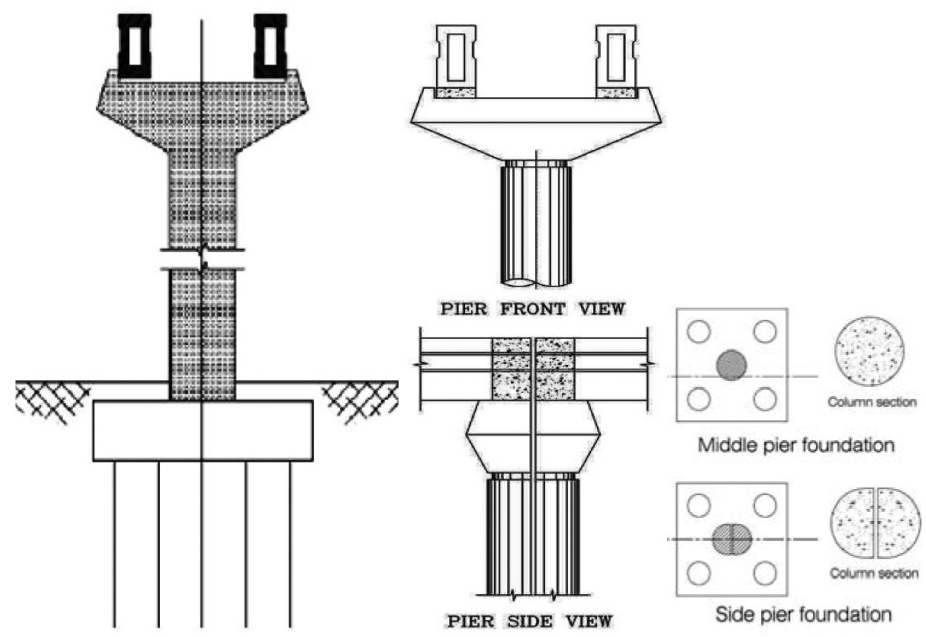

Fig. 5. The main components of the bridge structure

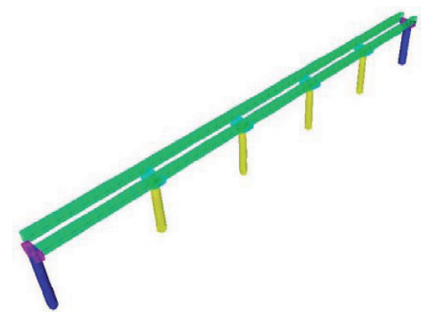

Fig. 6. The FE model of the monorail bridge structure 


\section{The results of dynamic simulations}

After completion of the coupled vehicle-bridge model in the MBD environment, the dynamic simulations were carried out. The braking forces between the train tires and guideway beams were present in the analysis, in addition to the dead weights of the components and the train live loads. The other load sources including earthquake, wind, lateral hunting, thermal, centrifugal and construction loads were not considered in the study.

Monorail vehicles are equipped with elaborate braking systems. For each bogie, there are two tubes getting into respective inputs of the brake calipers through the necessary detours. The brake discs are keyed to the ends of the motors axles. Depending on the situation, the vehicle stops in all conditions of loading and driving in safe mode. This is handled by the use of two independent braking systems i.e. electrical brake and mechanical brake. In the present study, the effect of the emergency brake on dynamic behavior of the system is examined. The emergency brake is available to be used by the driver or the automatic train operation center. This system stops the vehicle with the maximum deceleration rate in the shortest possible distance. Therefore, it is considered as a critical situation for dynamic interaction of the vehicle-bridge system. For this purpose, an emergency brake with $1.5 \mathrm{~m} / \mathrm{s}^{2}$ declaration was considered. Before braking, the initial speed of $80 \mathrm{~km} / \mathrm{h}$ is chosen as the maximum operational speed of the monorail system in this study. Dynamic simulations were performed for around the full passage of the train over the bridge.

Fig. 7 shows the arrangement of load-bearing tires in each monorail car, schematized by indicating their locations in the top view. The guiding tires are nor shown in this figure, as no lateral load is considered in the analysis.

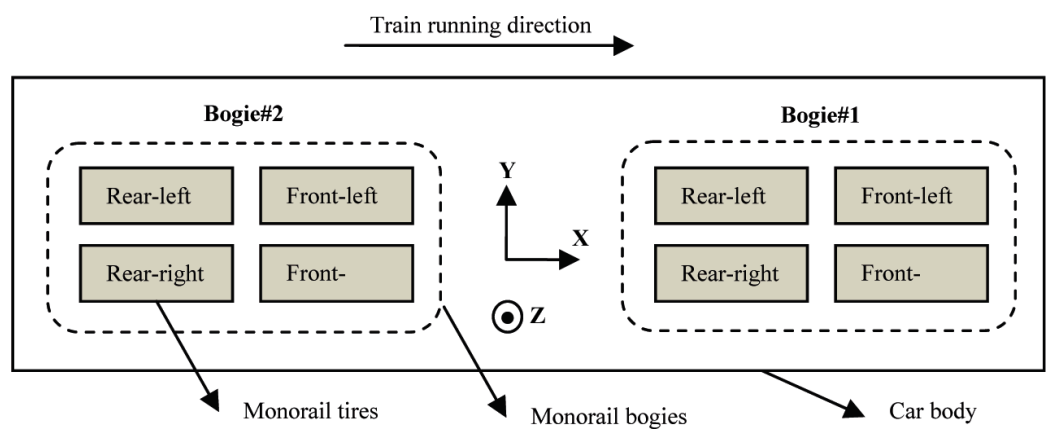

Fig. 7. The arrangement of load-bearing tires and bogies in each monorail car

The results of dynamic tire loads in the load-bearing tires are reported in Fig. 8, 9. The emergency brake was activated in the time zero, after which the tire forces were recorded till around 3.5 seconds. The initial jumps in these 
figures (between the zero and $0.5 \mathrm{sec}$ ) happened due to the intense declaration of the train. All the tire force graphs were started relatively with identical initial values corresponding to the static tire loads. During the emergency brake, the tire loads were either increased or decreased (relative to the static loads), depending on their arrangement in the car; see Fig. 7.
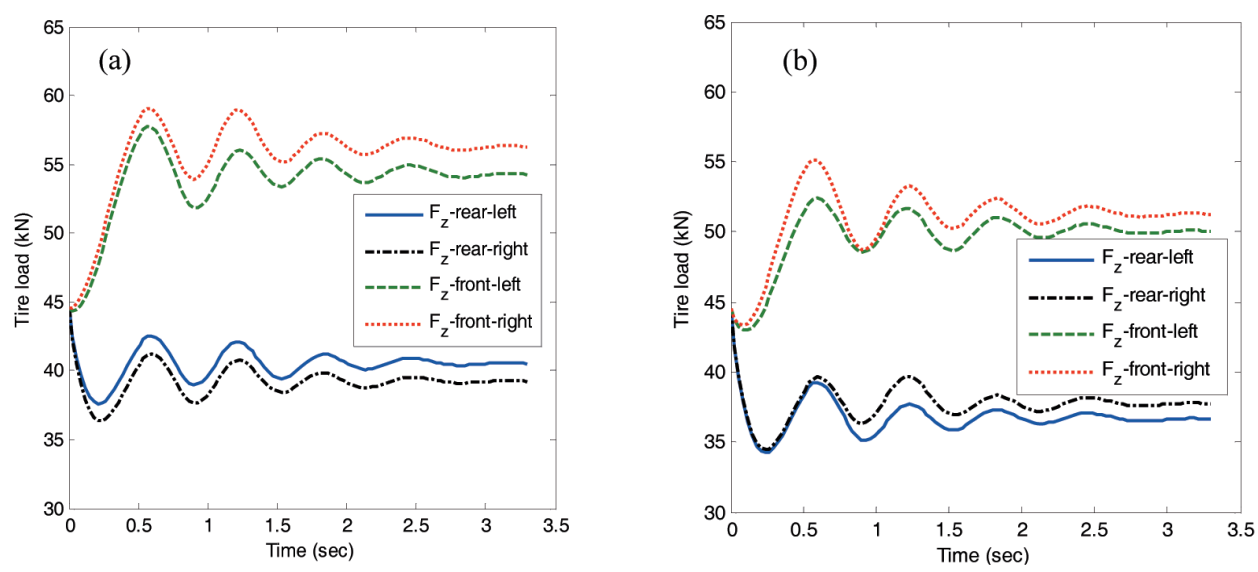

Fig. 8. The results of vertical tire loads due to emergency brake in the train,

(a) tires of the Bogie\#1, (b) tires of the Bogie\#2
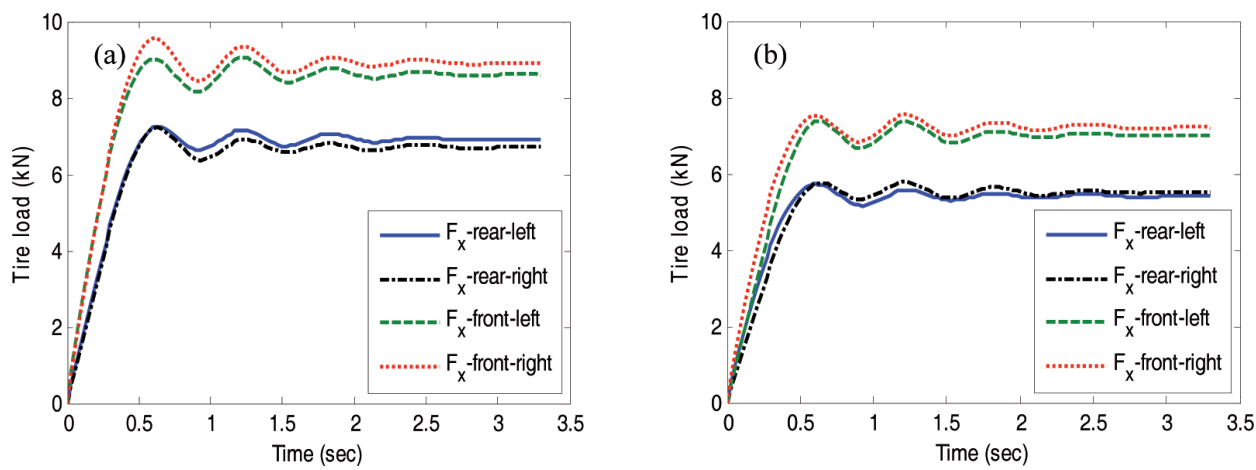

Fig. 9. The results of longitudinal tire forces due to the emergency brake in the train,

(a) tires of the Bogie\#1, (b) tires of the Bogie\#2

The dynamic tire forces reached steady-state conditions by around two seconds after the braking. The steady-state tire loads were different for various tires. Fig. 10 depicts the peaks and the steady state results of tire forces in the train. It should be noted that the abscissas refer to the tire locations in the longitudinal direction (wagon length). Looking at the results in Fig. 10, one can see that the forces in the front tires were more significant than those of rear tires. This is apparently due to the inertial forces of the components under the braking effects. Furthermore, the tires in Bogie\#1 (the front bogie of the 
car) experienced larger forces than in Bogie\#2 (the rear bogie). The difference between the forces in the left and the right tires was negligible as the lateral loads were disregarded in the analysis.
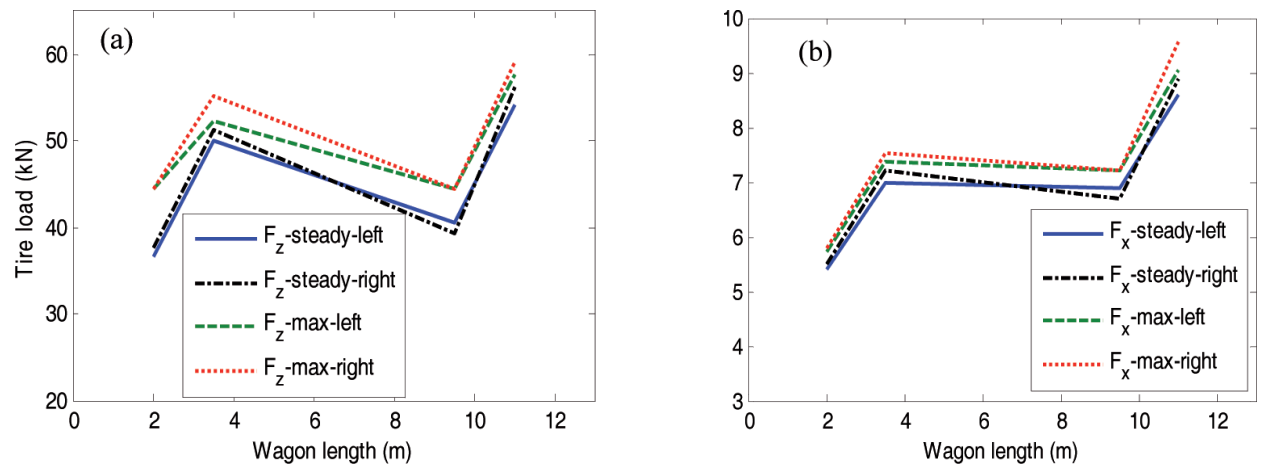

Fig. 10. The peak and steady state results of tire forces due to the emergency brake in the train, (a) vertical forces, (b) longitudinal forces

By comparing the dynamic tire forces with the corresponding static ones, one can measure the dynamic amplification factors (DAF) for each tire. The value of DAFs of the vertical tire forces were calculated as shown in Fig. 11. The results were calculated both for the maximum dynamic forces and the steady-state quantities. According to this figure, the maximum DAF of the tire force was obtained around 1.3 in the front tire of the first (front) bogie.
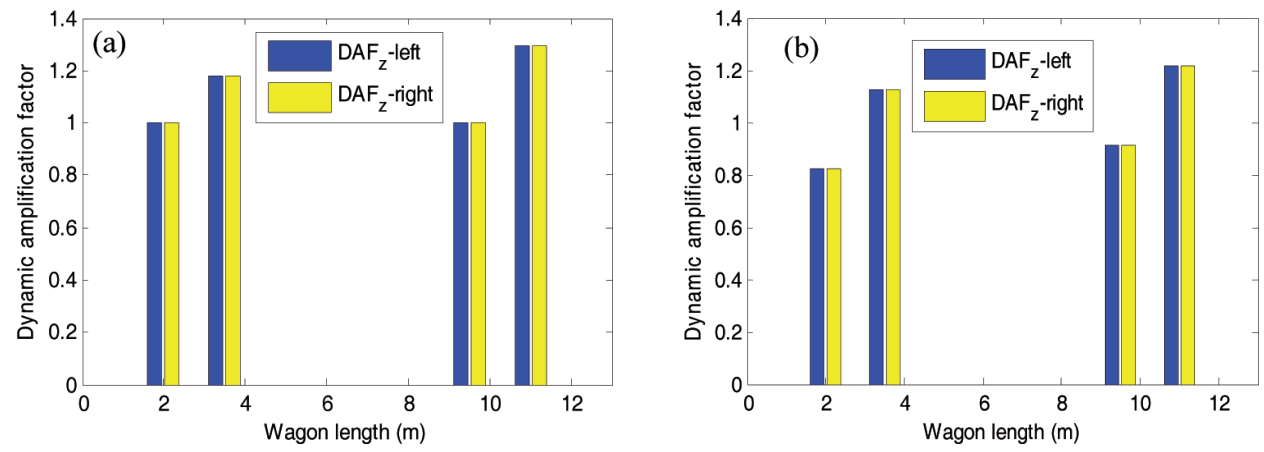

Fig. 11. The dynamic amplification factors of the vertical force in various tires, (a) peak dynamic forces, (b) steady-state forces

As shown in Fig. 4, two types of bridge piers can be distinguished in the typical spans, i.e. side piers and middle piers. The quantities of reaction forces in the piers can be extracted from dynamic simulations. Fig. 12 demonstrates the time histories of the reaction forces on the side pier $\mathrm{C} 1$ and the middle pier C3. The results are reported for the connection points of the beams (girders) to the pier caps. In this figure, the vertical and longitudinal forces are indeed the 
axial and shear forces acting on the piers, while the prescribed moment represents for the bending moment of the pier in the vertical plane.
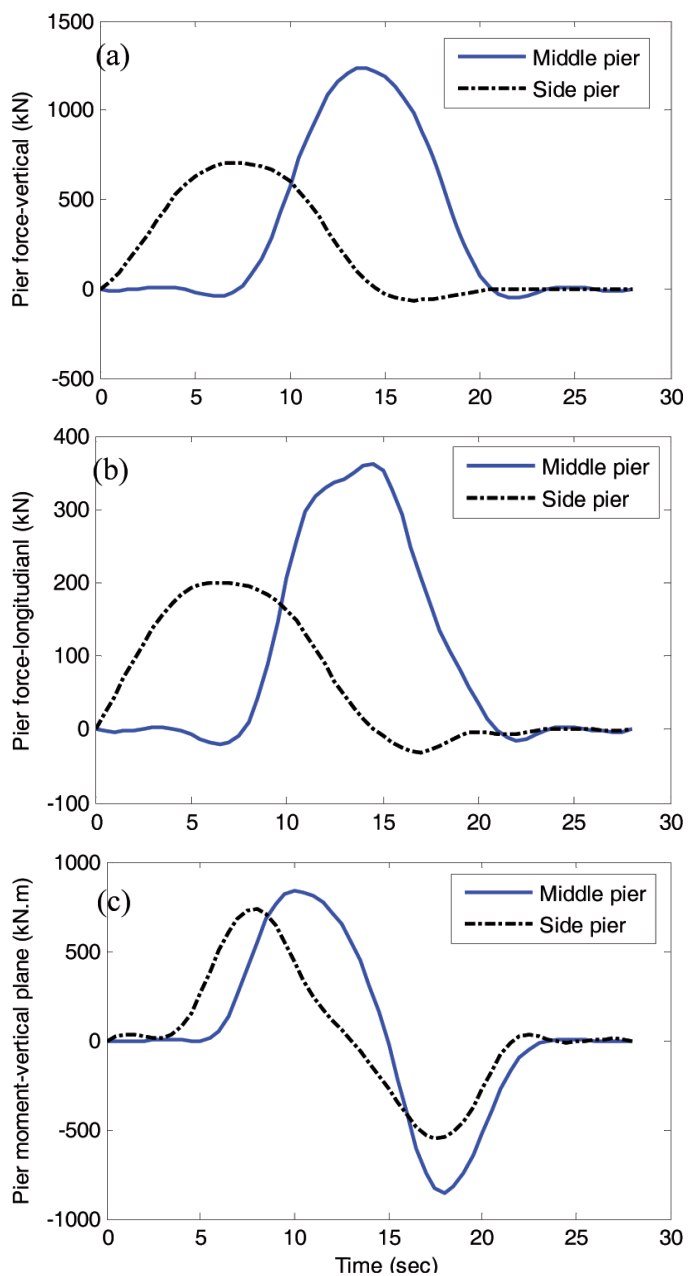

Fig. 12. The reaction forces applied on bridge piers, (a) vrtical force (b) longitudinal force, (c) moment in the vertical plane

The time histories of reaction forces were zero in the beginning of the simulation. As the train approached to the piers (the side or middle pier), dynamic excitations were revealed in the bridge piers. $\mathrm{C} 1$ was the first pier that experienced the train load, whereas, $\mathrm{C} 3$ experienced the train with the time shift. According to Fig. 12, the following observation can be made:

1) The negative reaction forces (vertical and longitudinal) just before and after the train passage were negligible for both piers. This means that piers are unlikely to experience the uplift force. 
2) The results of reaction forces in the middle pier were more significant than those of the side pier. This is apparently due to the continuous spans used in the bridge model.

3) The peak axial and shear forces in the side pier were around 720 and $200 \mathrm{kN}$, respectively. The quantities for the middle pier were around 1240 and $360 \mathrm{kN}$, respectively.

4) The peak bending moments in the side pier and the middle pier were around 840 and $750 \mathrm{kN} \cdot \mathrm{m}$, respectively.

\section{Summary}

Dynamic simulation of the coupled monorail train-bridge system was presented. A monorail vehicle consisting of four adjacent cars was modelled in the mulibody program MSC ADAMS. The guideway bridge was assumed to be straight with five continuous spans. Such a bridge system is numerically modelled by combining the finite element and multibody tools. The coupled model of the train and the monorail bridge system was built in the multibody environment. The dynamic interaction of the system was investigated due to the emergency brake of the vehicle.

By performing dynamic simulations, the time histories of tire forces were determined. Due to the inertial effects, the forces in the front tires were more significant than those of rear tires. Furthermore, the tires in the front bogie of the car experienced larger forces than in the rear bogie. The difference between the forces in the left and the right tires was negligible as the lateral loads were disregarded in the analysis.

The dynamic time histories of the reaction forces (axial force, shear force and bending moment) in the piers were recorded. Due to the application of continuous spans, the reaction forces in the middle piers were more significant than those of the side piers.

\section{Acknowledgement}

The authors are grateful to FCF Company, Qom Urban Railway Organization (QURO), Hexa Consulting Engineers, and the Keyson-Mapna consortium of contractors for providing general specifications of the train and the bridge system for this research. This research received no specific grant from any funding agency in the public, commercial or not-for-profit sectors. 


\section{REFERENCES}

[1] Lee, C.H., Kanbara, T., Nishimura, N., et al. Effect of train dynamics on seismic performance of steel monorail bridges under extreme ground motions. in Fourth International Conference on Current and Future Trends in Bridge Design, Construction and Maintenance. 2005. Kuala Lumpur, Malaysia: Thomas Telford.

[2] Lee, C.H., Kim, C.W., Kawatani, M., et al., Dynamic response analysis of monorail bridges under moving trains and riding comfort of trains. Engineering Structures, 2005. 27(14): p. 19992013.

[3] Lee, C.H., Kawatani, M., Kim, C.W., et al., Dynamic response of a monorail steel bridge under a moving train. Journal of Sound and Vibration, 2006. 294(3): p. 562-579.

[4] Ivanchenko, I., Substructure method in high-speed monorail dynamic problems. Mechanics of solids, 2008. 43(6): p. 925-938.

[5] Kim, C.W. \& Kawatani, M., Effect of train dynamics on seismic response of steel monorail bridges under moderate ground motion. Earthquake engineering \& structural dynamics, 2006. 35(10): p. 1225-1245.

[6] Liu, Y., Ge, Y., \& Yang, Y., The dynamic response analysis of the coupled system of the straddle type monorail train and the track beam. China Railway Science, 2010. 5: p. 004.

[7] Rybak, S.A., Makhortykh, S.A., \& Kostarev, S.A., Theoretical and experimental study of vibration, generated by monorail trains. The Journal of the Acoustical Society of America, 2002. 112(5): p. 2247-2248.

[8] Shi, Z., Pu, Q., \& Xia, Z. Research on dynamic testing of straddle-type monorail transit system in Chongqing city. in The Emerging Frontiers of Transportation and Development in China. 2009. ASCE.

[9] Shi, Z., Pu, Q.H., Gao, Y.F., \& Xia, Z.G., Dynamic testing of straddle-type monorail vehicles system in Chongqing city. Journal of Vibration and Shock, 2008. 12: p. 025.

[10] Wang, X., Li, W.B., \& Zhang, B.J., Finite element analysis and optimization of monorail structure of monorail vehicle for mountains. Guangdong Agricultural Sciences, 2012. 2: p. 049.

[11] Wen, X.X., He, Y.T., Du, Z.X., \& Zhang, X.X., Crash Simulation of Straddle-Type Monorail Vehicle Body and Human Injury Research. Advanced Materials Research, 2012. 413: p. 486490.

[12] Naeimi, M., Tatari, M., Esmaeilzadeh, A., \& Mehrali, M., Dynamic interaction of the monorail-bridge system using a combined finite element multibody-based model. Proceedings of the Institution of Mechanical Engineers, Part K: Journal of Multi-body Dynamics, 2015. 229(2): p. 132-151.

[13] Rolling stock design, report of manufacturer, dynamic clearances, load and force data exerted on guideway beams by FCF company, Italy and Qom Urban Railway Organization, Qom, Iran. 2011.

[14] Calculation leaflets, structural design of Qom monorail project by Hexa Consulting Engineers. 2011: Tehran, Iran.

\section{Dynamika pociągu jednoszynowego $w$ trakcie hamowaniu na prostym odcinku prowadnicy mostu}

\section{Streszczenie}

W pracy zastosowano metodę elementów skończonych do modelowania prostego odcinka prowadnicy mostu kolei jednoszynowej w celu badania oddziaływań dynamicznych, wzdłużnych i pionowych, występujących w systemie. Modelowano skok mostu kolei jednoszynowej, o ograniczonej 
długości, zawierający pięć odcinków ciągłych. Do badania systemu pociągu jednoszynowego zastosowano model 3D, realizowany w oprogramowaniu MCS ADAMS przeznaczonym do analizy systemu wielu ciał metodą elementów skończonych. Cały model, składający się z modelu pojazdu i podsystemów mostu, jest analizowany numerycznie drogą symulacji dynamicznej w dziedzinie czasu. W czasie analizy są aktywowane siły hamowania występujące pomiędzy oponami pociągu i belkami prowadnicy. Uwzględniono ciężar własny składników konstrukcji i ciężar użytkowy - pasażerów pociągu. Wyznaczono siły dynamiczne w oponach dla przypadku hamowania awaryjnego. Wyznaczono także siły reakcji w filarach mostu, które stanowią dane wejściowe dla celów projektowania mostu. 
